\title{
ASIAN DEVELOPMENT OUTLOOK
}

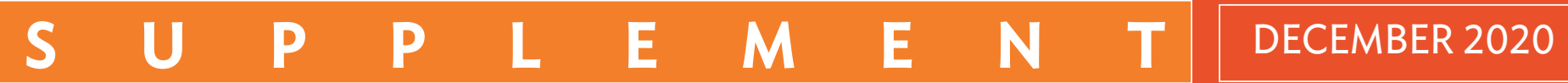

\section{HIGHLIGHTS}

- Developing Asia is now forecast to contract by $0.4 \%$ in 2020 , less than the $0.7 \%$ contraction envisaged in the Asian Development Outlook 2020 Update in September. Growth will rebound to $6.8 \%$ in 2021, but prospects diverge within the region.

- Projected growth in East Asia in 2020 is upgraded from $1.3 \%$ in the Update to $1.6 \%$ as the People's Republic of China and Taipei,China recover more quickly than expected. Growth in 2021 is still forecast at $7.0 \%$.

- The earlier South Asia forecast for $6.8 \%$ contraction is upgraded to $6.1 \%$ in line with an improved projection for India, as recovery accelerates, from $9.0 \%$ contraction to $8.0 \%$. Growth will return in 2021, at $7.2 \%$ in South Asia and 8.0\% in India.

- Recovery in Southeast Asia continues to lag as virus containment efforts in the larger economies hamper economic activity. Subregional forecasts are downgraded for 2020 from $3.8 \%$ contraction to $4.4 \%$, and for 2021 from $5.5 \%$ growth to $5.2 \%$.

- Growth forecasts for Central Asia and the Pacific are unchanged from September. Central Asia is still projected to contract by $2.1 \%$ this year, and the Pacific economies by $6.1 \%$ as global tourism continues to languish.

- Depressed demand and low oil prices will keep regional inflation in check at $2.8 \%$ in 2020 and $1.9 \%$ in 2021.

\section{PATHS DIVERGE IN RECOVERY FROM THE PANDEMIC}

\section{Recent developments}

Since the Asian Development Outlook 2020 Update, Coronavirus Disease 2019 (COVID-19) has continued to spread. The United States is currently suffering its third wave with an average of more than 160,000 new cases daily at the end of November. Europe is on its second wave, with new cases in the euro area exceeding 75,000 daily. Developing Asia has about 70,000 new cases daily, more than two-thirds of them in South Asia and almost all of the rest evenly divided between Central and Southeast Asia. East Asia has the virus largely under control, with just over 500 new cases daily, while the Pacific has so far avoided large outbreaks.

Despite the persistent spread of COVID-19, most economies have continued to relax containment measures, having deemed strict lockdowns to be economically unsustainable. Variation in the intensity of containment reflects the state of outbreaks in different economies. Containment remains relatively stringent in Central, South, and Southeast Asia, where outbreaks have continued in some economies and reemerged in others. Containment is less stringent in East Asia and the Pacific where outbreaks are under control or absent.

Consequently, mobility and economic activity have improved in these subregions in recent months. Subregional variations in mobility are consistent with those of containment. Domestic mobility is slightly below levels that prevailed before COVID-19 in East Asia and the Pacific. In subregions still dealing with serious outbreaks, domestic mobility remains below normal-by about 10\% in South Asia and 20\% in Central and Southeast Asia.

The Asian Development Bank Regional Economic Outlook Task Force led the preparation of a revised outlook for this Asian Development Outlook Supplement. The task force is chaired by the Economic Research and Regional Cooperation Department and includes representatives of the Central and West Asia Department, East Asia Department, Pacific Department, South Asia Department, and Southeast Asia Department. 
Regional merchandise exports have rebounded quickly, but recovery in tourism is taking much longer. After contracting in May by $16 \%$ year on year (as assumed unless otherwise noted), Asia's exports have recovered in recent months to levels similar to last year. Many categories of exports have fallen in response to weak external demand as the major advanced economies contract substantially this year, albeit by less than forecast in the September Update (box). These shortfalls have been offset by strong exports of health and medical equipment and supplies, and of electronics and household goods, demand for which has increased during the pandemic. Tourism exports remain abysmal as many travel restrictions to contain the pandemic remain in place. Available data show declines in tourist arrivals ranging from $88 \%$ to $100 \%$. Prospects for quick recovery in global tourism are muted. In a survey conducted by the International Air Transport Association in August, over half of respondents said that, even after travel restrictions were lifted, they would wait from 6 months to a year or longer before traveling.

\section{Growth outlook and risks}

As the pandemic lingers, developing Asia is projected to contract by $0.4 \%$ in 2020 , less than the $0.7 \%$ contraction envisaged in September (table). Contraction is still expected in all subregions except East Asia. Regional growth will rebound to $6.8 \%$ in 2021 , but output will remain below what was envisioned before the pandemic. Excluding the newly industrialized economies of Hong Kong, China; the Republic of Korea; Singapore; and Taipei,China, the regional gross domestic product (GDP) forecast is revised up from $-0.5 \%$ to $-0.3 \%$ in 2020 and maintained at $7.2 \%$ growth in 2021 .

A prolonged pandemic is still the main risk to the outlook, as it can derail recovery and undermine stability in some economies. Recent progress in developing vaccines tempers this risk, but vaccines must be not only safe and effective but also delivered widely in a timely way for developing economies to share equitably in the benefits. Another risk is worsening geopolitical tensions, most notably intensified friction between the US and the People's Republic of China (PRC) over trade and technology. Recent US election results may bring more predictability and multilateral approaches to resolving tensions between the world's two largest national economies, but full reconciliation will be a challenge.

\section{East Asia}

The largest subregional economy in developing Asia is the only one projected to grow in 2020, with the forecast upgraded from $1.3 \%$ to $1.6 \%$. In 2021, East Asia is expected to grow by $7.0 \%$. The PRC expanded its GDP by $4.9 \%$ in the third quarter (Q3) of 2020, restoring growth in the first 3 quarters to $0.7 \%$.
Recovery was faster in industry than services, with catering and accommodation catching up slowly. In the first 10 months of 2020 , value added in industry grew by $1.8 \%$ in real terms, reaching $6.9 \%$ in October, while retail sales declined by an estimated $7.6 \%$. In the same period, nominal investment in fixed assets grew by $1.8 \%$ as contraction in manufacturing investment roughly canceled out growth in real estate investment, and as infrastructure investment barely grew. Meanwhile, merchandise imports declined by $2.3 \%$ in the first 10 months of 2020, while exports, picking up in the second half (H2), rose by $0.5 \%$.

The PRC is now expected to grow by $2.1 \%$ in 2020 , more than the $1.8 \%$ forecast in the Update. This revision factors in consistent fiscal and monetary support, though another round of monetary easing seems unlikely. Consumption remains burdened by only gradual labor market recovery. Investment will be buoyed by government-financed infrastructure projects and a solid real estate market, while manufacturing investment is expected to languish. Economic growth is forecast to bounce back from a low base to $7.7 \%$ in 2021 , unchanged from the Update, but risks pertaining to global economic recovery make the forecast uncertain.

Contraction in Hong Kong, China eased from $9.0 \%$ in the first 2 quarters to $3.5 \%$ in Q3 on local COVID-19 stabilization, expansionary fiscal support, and recovering exports. Growth should improve further in Q4 as government relief prods domestic demand, household spending benefits from less stringent containment restrictions, and growth in the PRC lifts external demand. The GDP forecast is revised up to 5.5\% contraction in 2020 and maintained at 5.1\% growth in 2021.

In the Republic of Korea, GDP contraction improved from $2.7 \%$ in Q2 2020 to $1.3 \%$ in Q3. Private consumption contracted by $4.4 \%$ as unemployment remained high and consumer confidence dipped. Meanwhile, government consumption rose by $5.8 \%$, supported by supplemental budgets to cushion impact from the pandemic. Private investment managed to eke out growth at $0.6 \%$. GDP is now forecast to contract by $0.9 \%$ in 2020 , less than earlier projected, on stronger information technology exports, some recovery in private consumption, continuing fiscal and monetary support, and improved growth in major export markets. For 2021, a GDP growth forecast of 3.3\% is retained.

Taipei,China recovered in Q3, with growth accelerating from $0.6 \%$ contraction in Q2 to 3.3\%, driven by a surge in exports. Government consumption reversed $1.0 \%$ contraction in Q2 to grow by 3.2\%. Investment growth meanwhile slowed from $9.7 \%$ in Q2 to $2.0 \%$ as business confidence continued to waver. Private consumption decreased by $1.5 \%$, but this improved on $5.0 \%$ contraction in the previous quarter. GDP growth is expected to continue in Q4 as global demand for information technology products and other electronics continues to expand and consumer confidence improves. Growth is forecast at $1.7 \%$ in 2020 , higher than in the Update but entailing a base effect that slightly tempers the 2021 forecast to $3.3 \%$. 


\section{Outlook for the major advanced economies}

Contraction this year in the global economy will be milder than anticipated in the September Update. Unexpectedly strong third quarter (Q3) outcomes in the United States and the euro area prompt upward revisions to 2020 gross domestic product (GDP) forecasts. In aggregate, the major advanced economies are now expected to contract by $5.1 \%$ in 2020 before recovering to $4.4 \%$ growth in 2021 (box table).

Gross domestic product growth in the major advanced economies (\%)

\begin{tabular}{|c|c|c|c|c|c|}
\hline \multirow[b]{2}{*}{ Area } & \multirow{2}{*}{$\begin{array}{r}2019 \\
\text { Actual }\end{array}$} & \multicolumn{2}{|c|}{2020} & \multicolumn{2}{|c|}{2021} \\
\hline & & $\begin{array}{c}\text { September } \\
\text { ADO } 2020 \\
\text { Update }\end{array}$ & $\begin{array}{l}\text { December } \\
\text { ADOS }\end{array}$ & $\begin{array}{c}\text { September } \\
\text { ADO } 2020 \\
\text { Update }\end{array}$ & $\begin{array}{c}\text { December } \\
\text { ADOS }\end{array}$ \\
\hline $\begin{array}{l}\text { Major advanced } \\
\text { economies }\end{array}$ & 1.7 & -6.2 & -5.1 & 4.4 & 4.4 \\
\hline United States & 2.2 & -5.3 & -3.5 & 4.0 & 4.2 \\
\hline Euro area & 1.3 & -8.0 & -7.4 & 6.0 & 5.6 \\
\hline Japan & 0.7 & -5.4 & -5.4 & 2.0 & 2.3 \\
\hline
\end{tabular}

$A D O=$ Asian Development Outlook, $A D O S=$ ADO Supplement .

Note: Average growth rates are weighed by gross national income, Atlas method, in current US dollars.

Sources: Asian Development Bank. 2020. Asian Development Outlook 2020 Update; ADB estimates.

The US economy surprised on the upside in Q3 2020 despite a surge in COVID-19 cases, as containment eased and activity normalized more rapidly than expected. GDP growth reaccelerated quickly, by $33.1 \%$ quarter on quarter, but still left GDP down by $2.9 \%$ in seasonally adjusted annualized terms (as assumed in this box unless otherwise noted). The rebound reflected sharp recovery in private consumption and investment. Net exports dragged on growth as imports rose even more than exports. Government consumption decreased at all levels. Private consumption improved in Q3 by $40.7 \%$ quarter on quarter as both goods and services revived-with health care, catering, and accommodation driving growth in servicesbut remained down by $2.9 \%$ year on year.

With economic activity normalizing and supported by substantial stimulus payments, retail sales rallied in May 2020 and remained healthy in Q3. After strong recovery in June, consumer confidence has since recorded smaller improvements, reflecting concern over the persistent spread of COVID-19. Investment grew the most, rebounding by $83 \%$ quarter on quarter to its Q1 level but still down by $3.8 \%$ year on year. Residential investment and increased spending on equipment and retail inventories drove the recovery. Industrial production has picked up only gradually since June, but the purchasing managers' index (PMI) bounced back as its manufacturing component reached 59.3 in October. The labor market continued to improve, albeit more slowly, as unemployment fell from a peak of $14.7 \%$ in April to $6.9 \%$ in October.

With the Q3 rebound, GDP forecasts are revised up, from $5.3 \%$ contraction to $3.5 \%$ in 2020 and from $4.0 \%$ growth to $4.2 \%$ in 2021 . Stalling consumer confidence will likely preclude high consumption growth as in Q3, but the ongoing resumption of business activity should sustain investment growth. Interest rates will remain low but may not enable growth without renewed fiscal stimulus. Economic prospects remain clouded by resurgent infection, though this is offset by recent positive developments regarding vaccines.

The euro area saw a surprisingly strong Q3 rebound as easing restrictions spurred domestic demand. After record contraction in Q2 2020, by 39.5\% quarter on quarter or $14.8 \%$ year on year, growth in the euro area bounced back in Q3 by 61.1\% quarter on quarter, the sharpest increase since records began in 1995 but still down by $4.3 \%$ year on year. Expansion spanned all major euro area economies with dynamic exports, solid household spending as retail trade month on month reversed $1.8 \%$ contraction in July with $4.4 \%$ growth in August, and industrial production growth month on month at $5.0 \%$ in July, though slipping to $0.7 \%$ in August. The labor market remained stable with unemployment unchanged at $8.3 \%$ in September.

Economic sentiment held steady at 90.9 in October as the outlook improved for industry, construction, and retail trade, but leading indicators suggest a setback in Q4 after worsening COVID-19 numbers that month prompted renewed restrictions. The composite PMI declined from 50.4 in September to 49.4 in October, signaling renewed contraction. Business ebbed as manufacturing growth was offset by weaker services.

With governments in the currency bloc now tightening restrictions against a new COVID-19 wave, momentum is unlikely to carry over into Q4. The euro area is thus forecast to contract by $7.4 \%$ in 2020 before recovering to $5.6 \%$ growth in 2021 , buoyed by expansionary monetary and fiscal policies and strengthening external demand. The outlook is highly uncertain, possible downside risks being renewed restrictions, global trade tensions, a no-deal Brexit, and unsustainable public debt.

Japan rebounded from sharp contraction in Q2 2020 by $28.8 \%$ quarter on quarter, or $10.3 \%$ year on year, to record-breaking $21.4 \%$ growth quarter on quarter in Q3 as restrictions under a state of emergency eased-still leaving contraction by $5.9 \%$ year on year. Growth in Q3 was propelled by strong recovery in domestic consumption including services and higher government consumption owing to announced fiscal support, even as private investment dragged on growth.

Recovery should continue in Q4, albeit more slowly, if COVID-19 remains in check. A $4.0 \%$ rise month on month in 
Box Continued

industrial production in September bodes well for GDP growth in the second half of 2020. Bank of Japan's Tankan survey of business conditions showed improvement but remained deeply negative, which, combined with muted core machinery orders, suggests lagging recovery in capital expenditure. Meanwhile, retail sales fell only marginally in September as consumer sentiment improved and the unemployment rate held steady at $3.0 \%$. After 14 consecutive months of decline, export growth returned in October. The same month, the manufacturing PMI climbed to 48.7 , and the services PMI to 46.9 , both remaining mired in contractionary territory.
GDP is still forecast to contract by $5.4 \%$ this year, but the growth forecast for 2021 is revised up to $2.3 \%$. Recovery could surprise on the upside, bolstered by accommodative monetary policy and sustained government spending to boost consumption, support furloughed workers, and revive travel, entertainment, and other services industries-as well as by improving external demand. COVID-19 risk locally and worldwide clouds the outlook, but it may be mitigated by early and effective vaccines, for which the government has earmarked funds.

\section{South Asia}

With improved prospects for India, South Asia's growth forecast for 2020 is revised up to from $6.8 \%$ contraction to $6.1 \%$. The subregional growth projection for 2021 is revised up slightly from $7.1 \%$ to $7.2 \%$. Having contracted by $23.9 \%$ in Q1 of fiscal year 2020 (FY2020, ending 31 March 2021), the Indian economy began to normalize after containment measures started in ease in June, with economic contraction in Q2 FY2020 narrowing to 7.5\%, better than expected. Agriculture, manufacturing, and utilities grew year on year, while a decline in fixed investment improved from $47.1 \%$ in Q1 to 7.3\%. Net exports contributed 3.4 percentage points to growth in Q2. With the pandemic possibly having peaked in mid-September, many high-frequency indicators are better than a year ago or back to pre-COVID levels, indicating accelerating economic normalization. The GDP forecast for FY2020 is upgraded from $9.0 \%$ contraction to $8.0 \%$, with GDP in $\mathrm{H} 2$ probably restored to its size a year earlier. The growth projection for FY2021 is kept at $8.0 \%$.

In the rest of South Asia, economic activity started to normalize from Q3 2020, largely in line with Update projections. In Afghanistan, agriculture is robust, but the outlook is adversely affected by a new COVID-19 wave and intensified conflict even as peace talks continue. Economic activity in Bangladesh has recovered more strongly than expected with both exports and remittances growing in recent months but threatened by external risks as COVID-19 outbreaks renew in major export destinations. In Bhutan, the impact of COVID-19 is now expected to be greater than projected in the Update after a nationwide lockdown in August and September halted all economic activity. Maldives restored more international flights in October, but travel demand remains weak as restrictions are reinstated in major European markets, hampering tourism recovery.

Nepal has substantially eased restrictions since September, but a persistent rise in COVID-19 infections is holding back demand, in line with Update projections. Pakistan's economy is recovering, particularly in manufacturing and

construction, supported by government emergency relief. In Sri Lanka, economic recovery was under way in Q3, but a rapidly expanding outbreak from early October brought localized lockdowns and restrictions, their economic effects compounded by resurgent outbreaks in Sri Lanka's main export and tourist markets. These factors are expected to worsen contraction in 2020.

\section{Southeast Asia}

The GDP forecast for Southeast Asia is revised down from $3.8 \%$ contraction in the Update to $4.4 \%$ in 2020 and from $5.5 \%$ growth to $5.2 \%$ in 2021 . GDP forecasts in 2020 are downgraded for Indonesia, Malaysia, and the Philippines as COVID-19 containment hampers economic recovery. Meanwhile, success in reopening economies points to better growth prospects for Brunei Darussalam, Thailand, and Viet Nam. Forecasts are unchanged for Cambodia, the Lao People's Democratic Republic, Myanmar, Singapore, and Timor-Leste.

The Indonesian economy contracted by $3.5 \%$ in Q3, deepening contraction in the first 3 quarters of 2020 to $2.0 \%$. Private consumption and investment have declined further since the Update. The unemployment rate surged to $7.1 \%$ in August 2020, its highest since August 2011. COVID-19 has affected nearly 30 million people through reduced work hours, suspended employment, or job loss. With continued weakness, GDP is forecast to contract by $2.2 \%$ in 2020 before returning to growth in 2021 , at $4.5 \%$. Rising consumer confidence and spending under an economic recovery program will buoy growth in 2021, and investment will benefit from ongoing reform to improve the business climate and to boost trade through membership in the Regional Comprehensive Economic Partnership.

Malaysia greatly improved its rate of GDP contraction from $17.1 \%$ in Q2 2020 to $2.7 \%$ in Q3 as consumption picked up and exports of electronic and medical products expanded. Investment and private consumption declined by less in Q3, 
while public spending on supplies and services increased. Meanwhile, net exports turned positive for the first time since Q3 2019. Targeted movement restrictions in response to a spike in COVID-19 cases in October will scale back consumption and production in Q4. Weighed down by travel restrictions and lower external demand, GDP is projected to fall by $6.0 \%$ this year before bouncing back by $7.0 \%$ in 2021 .

The Philippine economy contracted by $10.0 \%$ in January-September 2020, reflecting muted consumer and business activity and confidence under the pandemic. With unemployment improving but still high at $10.0 \%$ in July, a decline in household consumption eased from $15.3 \%$ in Q2 to 9.3\% in Q3 as the economy gradually reopened and remittances from overseas workers rebounded. The unemployment rate improved further to $8.7 \%$ in October. Fixed investment, on the other hand, fell by $36.5 \%$ in Q2 and $37.1 \%$ in Q3. Government consumption continued to increase but at a decelerated pace. Exports contracted less than imports, mitigating GDP contraction. The GDP forecast for 2020 is downgraded to $8.5 \%$ contraction because household consumption and investment have fallen more than expected. The forecast for 2021 is maintained at $6.5 \%$ growth, assuming that public investment picks up and the global economy recovers.

Singapore contracted by $6.5 \%$ in January-September 2020 , though with improvement to $5.8 \%$ contraction in Q3. Construction and services languished while manufacturing expanded. GDP in Q4 will enjoy some support from improving business confidence and expanding manufacturing and services but will continue to be weighed down by travel restrictions and weak global demand. The GDP forecast is maintained at $-6.2 \%$ in 2020 but revised up to $5.1 \%$ in 2021 with further recovery expected in manufacturing, construction, and the external sector.

Thailand contracted by $6.4 \%$ in Q3 2020, but this almost halved a $12.1 \%$ decline in Q2. Merchandise trade, private investment, and private consumption gradually recovered as containment measures eased at home and in trade partners. Additional support came from continued expansion in public consumption and investment. The forecast for 2020 is adjusted up slightly from $8.0 \%$ contraction to $7.8 \%$, but the growth forecast for 2021 is revised down from $4.5 \%$ to $4.0 \%$.

In Viet Nam, growth accelerated from $0.4 \%$ in Q2 2020 to $2.6 \%$ in Q3, lifting average growth in January-September to $2.1 \%$. The growth forecast for 2020 is revised up from $1.8 \%$ to $2.3 \%$ on the strength of accelerated public investment, revived domestic consumption, trade expansion, and rapid recovery in the PRC. The growth forecast for 2021 is revised down to $6.1 \%$.

\section{Central Asia}

The subregional GDP projection for 2020 is maintained at $2.1 \%$ contraction but revised down marginally for 2021 , from $3.9 \%$ growth in the Update to $3.8 \%$ in this Supplement. GDP forecasts for Kazakhstan, the subregion's largest economy, are unchanged at $3.2 \%$ contraction in 2020 and $2.8 \%$ growth in 2021 . In January-October 2020, the economy contracted by $2.9 \%$, with services suffering the most. A decline in real household income was mitigated somewhat by heightened social protection from the state. Oil production continued to be constrained under an agreement brokered by the Organization for the Petroleum Exporting Countries (OPEC). A sharp rise in the number of COVID-19 cases in the first week of November prompted the government to reintroduce strict quarantine in two regions, limit the number of flights, and suspend visa-free entry for the citizens of 57 countries until 1 May 2021. Recovery is expected in 2021 as restrictions are gradually removed.

The Armenian economy contracted by $5.7 \%$ in the first half of 2020, and the country's economic activity index indicated even deeper contraction by $6.6 \%$ in the first 9 months of the year. A surge in COVID-19 cases from midSeptember and recent military clashes with Azerbaijan are expected to drag on GDP in 2020, and the pace of recovery will be gradual in 2021, prompting this Supplement to adjust downward Armenia's GDP projections for both years. By contrast, Tajikistan recorded robust growth at $4.2 \%$ in the first 9 months of 2020, which is credited to timely support from the government and higher agricultural output with intensified land utilization. The growth projection for Tajikistan is revised up for 2020 but down for 2021. Forecasts for other Central Asian economies remain unchanged.

\section{The Pacific}

Economic contraction in the Pacific is projected at $6.1 \%$ in 2020, as forecast in the Update, under the continuing global impact of the COVID-19 pandemic. However, the unchanged subregional forecast masks some divergence in individual performance. In Palau, which is among the Pacific economies most driven by tourism, the pause in visitor arrivals caused GDP contraction in the fiscal year to September 2020 that was worse than previously forecast. Conversely, a surprisingly favorable fiscal outturn allowed Nauru to stave off projected economic contraction and post modest growth in the fiscal year to June 2020. Elsewhere in the Pacific, 2020 GDP forecasts are maintained.

Subregional growth is expected at $1.3 \%$ in 2021 , as projected in the Update. Although forecasts are largely retained, risks have tilted to the downside, with the Marshall Islands, Samoa, Solomon Islands, and Vanuatu recording their first cases of COVID-19 in the last quarter of 2020. Any local outbreaks are likely to necessitate tighter movement restrictions, which will further dent domestic demand. 


\section{Inflation outlook}

The 2020 inflation forecast for developing Asia is revised down slightly from $2.9 \%$ to $2.8 \%$ in this Supplement, reflecting continued depressed demand and low oil prices. In 2021 , inflation is expected to ease further to $1.9 \%$, lower than envisaged in the Update (table).

Brent crude oil prices in the year to 25 November averaged $\$ 41.55 /$ barrel, $35 \%$ below the same period last year. Several factors have held down oil prices: resurgent COVID-19 cases in the major advanced economies, decline in travel demand, a scheduled OPEC production increase agreed for next January, and oil production recovery in Libya. Countering these factors are upward pressure from a continuing rise in oil imports of the PRC, a seasonal increase in demand for heating oil, and recent positive news about COVID-19 vaccines. However, high oil inventories and excess production capacity will limit upward pressure on oil prices. Price forecasts for Brent crude are thus retained at $\$ 42.50 /$ barrel in 2020 and $\$ 50.00$ in 2021 .

The inflation forecast for East Asia is revised down from $2.6 \%$ to $2.2 \%$ for 2020 and from $1.7 \%$ to $1.2 \%$ for 2021 . In the PRC, consumer prices increased by an average of $3.0 \%$ in the first 10 months of 2020, up from $2.6 \%$ a year earlier. Inflation was driven by a $13.2 \%$ increase in food prices led by pork price inflation, which stood at $25.5 \%$ year on year in September but then went into reverse, declining by $2.8 \%$ year on year in October. Nonfood inflation moderated by a full percentage point from a year earlier to average $0.4 \%$ in the first 10 months of 2020 , and producer prices declined by $2.0 \%$, reflecting lower global oil prices. Inflation forecasts for the PRC are adjusted down by 0.4 percentage points to $2.6 \%$ in 2020 and by 0.6 points to $1.2 \%$ in 2021 because pork price inflation turned negative a bit earlier than previously expected and nonfood inflation is likely to remain subdued as domestic consumer demand recovers only gradually.

Elsewhere in East Asia, deflation continued in Hong Kong, China, for a fourth month in a row, at $0.2 \%$ in October 2020. Despite an improving GDP performance in the second half of the year, prices are likely to remain subdued for the rest of 2020 as COVID-19 keeps the local and global economies weak. This Supplement cuts the 2020 inflation forecast to $0.8 \%$ but maintains the 2021 forecast at $2.5 \%$. In the Republic of Korea, inflation in January-October remained muted at $0.5 \%$, held down by falling global fuel prices and subdued domestic demand. Update inflation forecasts $-0.5 \%$ in 2020 and $1.3 \%$ in 2021 -are maintained as current price trends remain within expectations. In Taipei,China, a deflationary trend from February to October will likely persist until the end of the year with low oil prices.
The forecast for 2020 is revised down to $0.2 \%$ deflation but upgraded for 2021 to a $1.1 \%$ rise as inflationary pressure revives.

The inflation projection for South Asia in 2020 is raised from $5.2 \%$ in the Update to $6.2 \%$, largely to accommodate a 2020 inflation projection for India revised up from $4.5 \%$ in the Update to $5.8 \%$. The subregional inflation projection for 2021 is kept at $4.5 \%$. In India, supply chain disruption brought food inflation to an average of $9.1 \%$ in the first 7 months of FY2020, pushing headline inflation to $6.9 \%$ in the same period. Indian inflation is expected to ease in the coming months, and the $4.0 \%$ Update projection for FY2021 is maintained. Similarly, surging food inflation pushed headline inflation in Bhutan up to 7.7\% in Q1 FY2021 (ending 30 June 2021). Average inflation in Bangladesh likewise rose to $5.9 \%$ in the first 4 months of FY2021 (ending 30 June 2021). By contrast, Maldives unexpectedly fell into deflation by an average of $1.4 \%$ in the first 3 quarters of 2020 as households received COVID-19 relief in the form of utility subsidies. In the rest of South Asia, inflation trends are in line with Update projections.

Inflation forecasts for Southeast Asia as a whole are revised up for 2020 but down for 2021. Inflation forecasts for 2020 are raised for Brunei Darussalam, Cambodia, Malaysia, the Philippines, Thailand, Timor-Leste, and Viet Nam; lowered for the Lao People's Democratic Republic; and maintained for Indonesia, Myanmar, and Singapore. With economic revival, deflation in Malaysia and Thailand has been milder than expected in the Update, averaging in January-September of this year $1.0 \%$ in Malaysia and $0.9 \%$ in Thailand. The inflation forecast for Viet Nam is revised up to $3.5 \%$ as floods in the center of the country may exert pressure on food prices.

Inflation forecasts for Central Asia are revised down, from $8.3 \%$ to $7.8 \%$ for 2020 and from $6.6 \%$ to $6.5 \%$ for 2021 . Crimped demand under various restrictions is expected to restrain inflation. With inflation in Kazakhstan averaging $6.7 \%$ in the first 10 months of the year, the projection for the whole of 2020 is adjusted down from $7.7 \%$ in the Update to $7.4 \%$ in this Supplement. Projections for this year are similarly revised down for Armenia, Azerbaijan, Georgia, Tajikistan, and Turkmenistan.

The 2020 inflation outlook for the Pacific is cut from $2.8 \%$ in the Update to $2.3 \%$. Inflationary pressures stemming from supply chain disruption under COVID-19 have been less severe in the Cook Islands, Fiji, and Nauru than previously anticipated. Further, Fiji has reduced some tax rates and import duties to facilitate economic recovery. The subregional inflation projection for 2021 is likewise reduced, but only slightly, from $3.1 \%$ in the Update to $3.0 \%$. 
GDP growth rate and inflation, \% per year

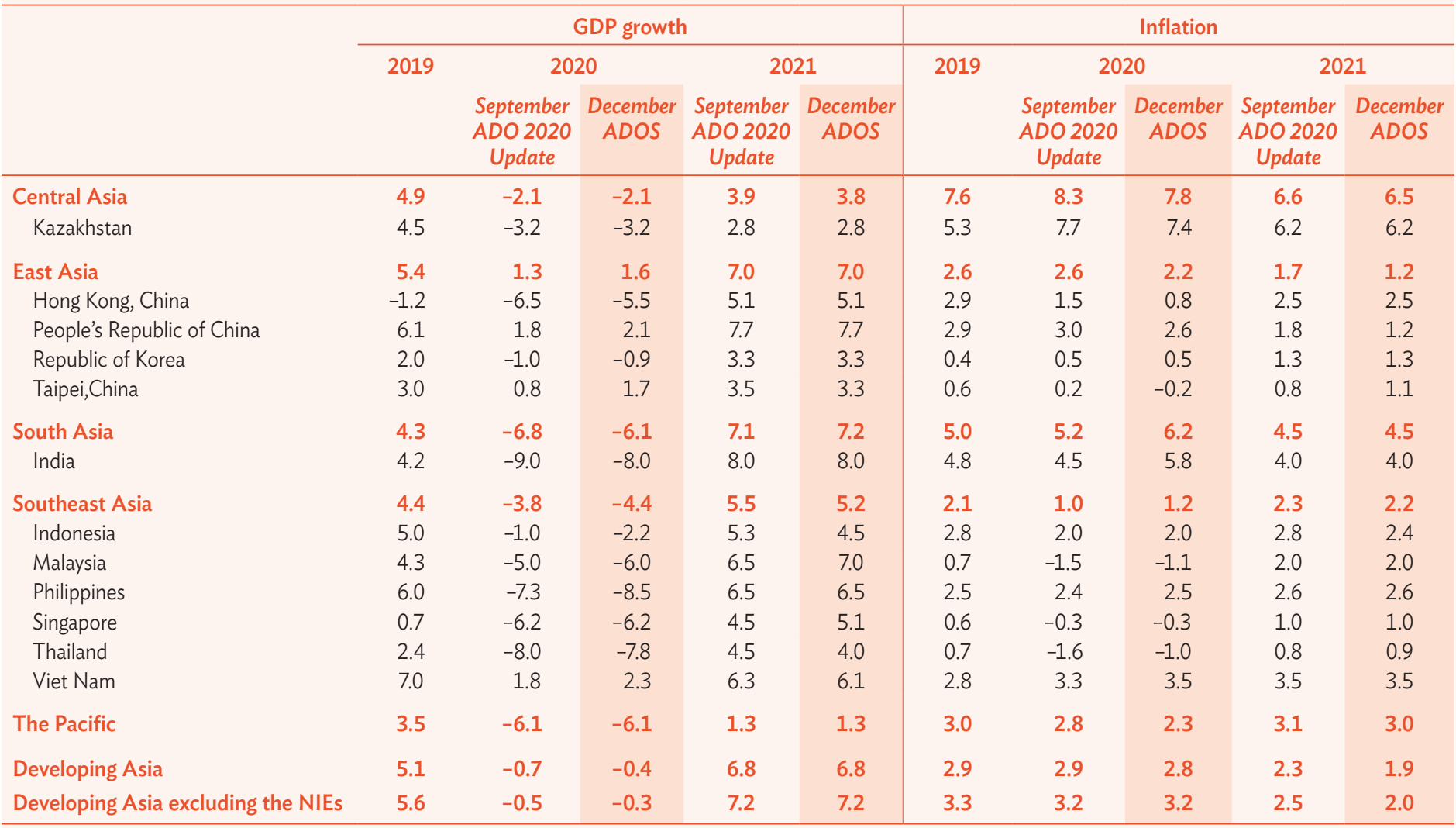

$\mathrm{ADO}=$ Asian Development Outlook, ADOS = ADO Supplement, GDP = gross domestic product, NIEs = newly industrialized economies of Hong Kong, China; the Republic of Korea; Singapore; and Taipei,China.

Note: Developing Asia refers to the 46 members of the Asian Development Bank listed below. Central Asia comprises Armenia, Azerbaijan, Georgia, Kazakhstan, the Kyrgyz Republic, Tajikistan, Turkmenistan, and Uzbekistan. East Asia comprises Hong Kong, China; Mongolia; the People's Republic of China; the Republic of Korea; and Taipei,China. South Asia comprises Afghanistan, Bangladesh, Bhutan, India, Maldives, Nepal, Pakistan, and Sri Lanka. Southeast Asia comprises Brunei Darussalam, Cambodia, Indonesia, the Lao People's Democratic Republic, Malaysia, Myanmar, the Philippines, Singapore, Thailand, Timor-Leste, and Viet Nam. The Pacific comprises the Cook Islands, the Federated States of Micronesia, Fiji, Kiribati, the Marshall Islands, Nauru, Niue, Palau, Papua New Guinea, Samoa, Solomon Islands, Tonga, Tuvalu, and Vanuatu.

Sources: Asian Development Bank. 2020. Asian Development Outlook 2020 Update; ADB estimates.

Asian Development Outlook Supplement

Asian Development Outlook is the main economic forecasting product from ADB. It is published each April with an Update published in September and brief Supplements published in July and December.

Asian Development Bank

$A D B$ is committed to achieving a prosperous, inclusive, resilient, and sustainable Asia and the Pacific, while sustaining its efforts to eradicate extreme poverty. Established in 1966, it is owned by 68 members -49 from the region. Its main instruments for helping its developing member countries are policy dialogue, loans, equity investments, guarantees, grants, and technical assistance.

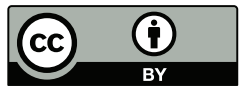

Creative Commons Attribution 3.0 IGO license (CC BY 3.0 IGO)

(c) 2020 Asian Development Bank

6 ADB Avenue, Mandaluyong City, 1550 Metro Manila, Philippines

Tel +6328632 4444; Fax +63286362444

www.adb.org

Some rights reserved. Published in 2020

ISBN 978-92-9262-571-9 (print); 978-92-9262-572-6 (electronic)

Publication Stock No. FLS200389-3

DOI: http://dx.doi.org/10.22617/FLS200389-3

The views expressed in this publication are those of the authors and do not necessarily reflect the views and policies of the Asian Development Bank (ADB) or its Board of Governors or the governments they represent. By making any designation of or reference to a particular territory or geographic area, or by using the term "country" in this document, ADB does not intend to make any judgments as to the legal or other status of any territory or area.

This work is available under the Creative Commons Attribution 3.0 IGO license (CC BY 3.0 IGO) https://creativecommons.org/licenses/by/3.0/igo/. By using the content of this publication, you agree to be bound by the terms of this license. For attribution, translations, adaptations, and permissions, please read the provisions and terms of use at https://www.adb.org/terms-use\#openaccess.

This CC license does not apply to non-ADB copyright materials in this publication. Please contact pubsmarketing@adb.org if you have questions or comments with respect to content or permission to use. Corrigenda to ADB publications may be found at http://www.adb.org/publications/corrigenda.

Notes:

In this publication, “\$” refers to US dollars. ADB recognizes "China” as People's Republic of China and "Vietnam" as Viet Nam 